\title{
MECHANICAL PROPERTIES OF HYBRID FRP BARS AND NANO-HYBRID FRP BARS
}

\author{
E.D. SZMIGIERA ${ }^{1}$, K. PROTCHENKO ${ }^{2}$, M. URBAŃSKI ${ }^{3}$, A. GARBACZ $^{4}$
}

The paper describes the recent developments of Hybrid Fibre-Reinforced Polymer (HFRP) and nano-Hybrid FibreReinforced Polymer (nHFRP) bars. Hybridization of less expensive basalt fibres with carbon fibres leads to more sustainable alternative to Basalt-FRP (BFRP) bars and more economically-efficient alternative to Carbon-FRP (CFRP) bars. The New-Developed HFRP bars were subjected to tensile axial loading to investigate its structural behaviour. The effect of hybridization on tensile properties of HFRP bars was verified experimentally by comparing the results of tensile test of HFRP bars with non-hybrid BFRP bars. It is worth to mention that the difference in obtained strength characteristics between analytical and numerical considerations was very small, however the obtained results were much higher than results obtained experimentally. Authors suggested that lower results obtained experimentally can be explained by imperfect interphase development and therefore attempted to improve the chemical cohesion between constituents by adding nanosilica particles to matrix consistency.

Keywords: Fibre-Reinforced Polymers (FRP) bars; Hybrid FRP (HFRP) bars; nano-HFRP (nHFRP) bars; composite reinforcement; Finite Element Analysis (FEA) for FRP bars

\section{INTRODUCTION}

For reinforced concrete $(\mathrm{RC})$ structures subjected to aggressive environments (e.g. de- icing salts in structures, marine structures, etc.), combinations of moisture, temperature and chlorides may result

\footnotetext{
${ }^{1}$ PhD., DSc., Eng., Warsaw University of Technology, Faculty of Civil Engineering, Al. Armii Ludowej 16, 00-637 Warsaw, Poland, e-mail: e.szmigiera@il.pw.edu.pl

${ }^{2}$ MSc., Eng., Warsaw University of Technology, Faculty of Civil Engineering, Al. Armii Ludowej 16, 00-637 Warsaw, Poland, e-mail: k.protchenko@il.pw.edu.pl

${ }^{3}$ PhD., Eng., Warsaw University of Technology, Faculty of Civil Engineering, Al. Armii Ludowej 16, 00-637 Warsaw, Poland, e-mail: m.urbanski@il.pw.edu.pl

${ }^{4}$ Prof., PhD., DSc., Eng., Warsaw University of Technology, Faculty of Civil Engineering, Al. Armii Ludowej 16, 00637 Warsaw, Poland, e-mail: a.garbacz@il.pw.edu.pl
} 
in the corrosion of reinforcing steel, leading to the deterioration of concrete and loss of structural serviceability [7]. This fact provides an indication of the big financial burden associated with the replacement of the deteriorated structures with the new materials, which has been approximately estimated to be twice the original construction cost $[11,17]$. For this reason, the search on the possibility of using an alternative solution to the steel reinforcement has been carried out over a dozen of years. One of the solutions is to use relatively corrosion resistant, non-metallic material, such as Fibre-Reinforced Polymer (FRP) materials [10].

FRPs become more and more recognizable and widely used materials in construction sector. A few decades ago it was difficult to imagine the use of FRP composites for so many building purposes, for reinforcing either enhancing building structures. Traditionally, it can be used in cases when its unique characteristics can be the most appropriate for the considered design purpose [34].

FRP bars are increasingly used as internal reinforcement for concrete structures. The strength, durability and stability are the main criteria for selection and design of FRP [7, 22, 23, 38]. It can be also applied for the cases where electrical or magnetic transparency of the materials is required [23]. Additionally, FRP bars are used to structurally strengthen existing masonry, concrete or wood members [21,32]. A different technical characteristics of FRP bars makes designing structures with FRP reinforcement differs from conventional reinforced concrete design [1].

The progress in Fibre-Reinforced Polymers (FRP) technologies pursued to introduce the new types of FRP bars for which will be feasible to adjust the sustainability and economic aspects. This provides designers with an added degree of freedom in selecting composites with the desirable stiffness, strength, dimensional stability, energy absorption, failure strain, corrosive resistance, the cost and other required characteristics.

An extensive research on the use of FRP bars for RC structures is being conducted at Warsaw University of Technology (Poland). The research is aimed at investigation of structural performance FRP bars for RC structures and determining the reliable FRP bar type that will balance safety and cost parameters [30]. The development of the new kinds of FRP bars is one of the parts to be investigated under current research.

The necessity of such investigation appeared since the commercially available types of FRP bars as a rule either less expensive and their properties are too low comparing to steel, either their properties are very good, but too expensive. Additionally, due to linear elastic behaviour of FRP bars, the flexural behaviour of FRP reinforced beams exhibits no ductility as occurs in the structures reinforced with steel bars $[18,29,27]$. Some authors suggest that hybridization of FRP bars influences on its behaviour making it semi-ductile instead of linear. 
The BFRP bars has the potential to offer an efficient and cost-effective solutions as an internal reinforcement for concrete structures. However, there is a lack of recommendations for the use of BFRP bars in the available design codes and guides, such as: ACI440.6R (2017) [3], CSA S6 (2014) [12] and CSA S806 (2012) [13, 17]. Many experimental tests were made under research programme for the members reinforced internally with BFRP bars. The BFRP bars used in RC structures are expected to provide more benefits that are comparable or superior to other FRP types while being significantly cost effective [16,37].

The experimental testing on strength performance of concrete beams reinforced with BFRP bars described in $[28,34]$ shows that the deflections of beams reinforced with BFRP bars are higher than deflections of beams reinforced with steel bars in approximately five times that may cause a concrete crushing of the compression zone before obtaining balanced ratio between reinforcement and concrete strength characteristics. The reason for such deflections is relatively low modulus of elasticity comparing to steel bars. There are two main solutions for this issue, the beams can be overreinforced with BFRP bars, either another type of FRP bars can be used [4].

Carbon fibres are suitable from the point of sustainability, however, they are energy intensive to manufacture making them expensive financially and environmentally [33]. As an alternative approach, the Hybrid FRP (HFRP) bars can be proposed, which are composed of basalt and carbon fibres (HC/BFRP) bars. Obtained HFRP bars are characterized by better mechanical properties than BFRP bars and more rentable cost than CFRP bars [20]. Since there were only two types of fibres used, the HC/BFRP bars will be called HFRP bars hereafter.

Processing HFRP bars is analogous to the process of producing BFRP bars, certain amount of the basalt roving has been replaced with carbon roving during the pultrusion process. In addition, two different adhesive agents were used, the conventional epoxy resin was used for one part of HFRP bars and for another part the epoxy resin was modified with nanosilica to improve the chemical cohesion between agents, which will be called nHFRP bars hereafter.

\section{PROPOSED HFRP AND NHFRP BARS}

\subsection{The STRUCTURE OF NEW-DEVELOPED BARS}

Hybridization of different constituents leads to a desirable combination of performance, cost and environmental attributes. It means the use of two or more fibre types with a single or several matrix 
types can give a rise to a more favourable balance between advantages and disadvantages of the core components $[15,24]$.

It is worth mentioning that characteristics and durability of HFRP bars depends on the following factors:

- The selection and properties of constituents

- The quality of developed bars (manufacturing process)

- The interphase development (bond behaviour)

Basing on the constituents there were two different groups of HFRP bars. One group was created by physical combination of two types of fibres, namely basalt and carbon fibres, embedded in a single matrix, epoxy resin (HFRP bars) and the second group contained the same fibres types embedded in epoxy resin modified with silica nanoparticles (nHFRP bars). The proposed new-developed bars were estimated on the influence of several factors, such as: location of fibres, technological aspects, different volume fraction ratio of fibres, influence of modified matrix.

The carbon fibres are characterized by high anisotropy and were selected due to its high mechanical properties in longitudinal direction. The Low Strength (LS) carbon fibres were chosen, among other types of carbon fibres, since it has the most close extension parameters to selected basalt fibres.

Basalt fibres are inorganic fibres that are made of very thin basalt filaments. These fibres are characterized by high tensile strength, better chemical resistance, extended operating temperature range, environmental friendliness, including environmentally friendly manufacturing process [34]. It exhibits small variations in physical properties along different molecular axes and classified as weak anisotropic material. The mechanical behaviour of basalt fibres is similar to the behaviour of carbon and glass fibres, however this kind of fibres has better physical and mechanical properties than some types of glass fibres and are more cost-effective than majority of types of carbon fibres.

The epoxy resin, which is an isotropic material, plays a key role in bonding of constituents and in turn it defines composite material performance in transverse direction. According to $[9,25,26]$, the adding of nanosilica particles into the epoxy resin improves the general performance of composite material and allows to achieve:

- extending life of the composition and reducing the thermal reaction effect, lowering the temperature peak during gelation and curing

- increasing thermal conductivity of the hardened resin and reducing thermal expansion

- improvement of some mechanical properties, such as hardness and compressive strength as well as modulus of elasticity

- $\quad$ reducing of internal stresses in hardened resin 
- the ability to modify dielectric properties, in particular to improve the dielectric resistance The properties of constituents are provided in Table 1 [30].

Table 1. Properties of Constituents Utilized for Preparing HFRP Bars

\begin{tabular}{|c|c|c|c|}
\hline Material property & Epoxy resin & Carbon & Basalt \\
\hline Density $(\mathrm{g} / \mathrm{cm} 3)$ & 1.16 & $1.90-2.10$ & $2.60-2.80$ \\
\hline Diameter $(\mu \mathrm{m})$ & - & 7.0 & 11.2 \\
\hline $\mathrm{E}_{11}(\mathrm{GPa})$ & 3.45 & 232.00 & 89.00 \\
\hline $\mathrm{E}_{22}(\mathrm{GPa})$ & 3.45 & 15.00 & 89.00 \\
\hline$v_{12}$ & 0.35 & 0.279 & 0.26 \\
\hline$v_{23}$ & 0.35 & 0.49 & 0.26 \\
\hline $\mathrm{G}_{12}(\mathrm{MPa})$ & 1.28 & 24.00 & 21.70 \\
\hline $\mathrm{G}_{23}(\mathrm{MPa})$ & 1.28 & 5.03 & 21.70 \\
\hline$\sigma_{11}(\mathrm{MPa})$ & 55 & 2500 & 1153 \\
\hline
\end{tabular}

* Where: $E_{i i}$ is the Young 's modulus along axis $i, v_{i j}$ is the Poisson ratio that corresponds to a contraction in direction $j$ when an extension is applied in direction $i$, and $G_{i j}$ is the shear modulus in direction $j$ on the plane whose normal is in direction $i, \sigma_{i i}$ is the tensile strength in the direction $i$.

For the experimental testing the epoxy resin with a four-component 1300 System ${ }^{\circledR}$ was used, which is dedicated to the manufacturing of composite materials using the pultrusion method. The sol with the nanosilica particles with a concentration of 25 to $30 \%$ by weight was used. Average diameter of particles was equal $24,7 \mathrm{~nm}$, containing two fractions: fine $(80 \%)$ and coarse $(20 \%)$.

\subsection{The Analytical Considerations}

As it is suggested in literature $[8,10,36]$, the longitudinal mechanical properties of composite materials with continuous fibres, including HFRP bars, can be obtained using the Rule of Mixtures (ROM) (axial loading - Voigt model). As it can be seen from the ROM, the properties of composite materials strongly depend on the volume fractions ratio, independently to the required property. The Young`s modulus was considered as a required property due to its importance in structural design. Basic mechanical properties, such as longitudinal modulus, may be applied for that case as it follows from the expression (2.2.1): 


$$
E_{11, i F R P}=\sum_{j} E_{11, f j} V_{f j}+E_{m} V_{m}
$$

where:

$E_{11, f j}$ - Young`s modulus of fibres along longitudinal axis, $V_{f j}$ - volume fraction of fibres; $E_{m}$ - Young`s modulus of matrix, $V_{m}$ - volume fraction of matrix.

Due to unknown behaviour of HFRP bars with modified resin, it was suggested to not consider the analytical and numerical analyses of nHFRP bars.

Consequently, various combinations of volume fractions between carbon and basalt fibres $(\mathrm{C}: \mathrm{B})$ were proposed for analytical considerations: $1: 1,1: 2,1: 3,1: 4$ and 1:9. The assumption was made that the volume fraction of matrix should be not less than $20 \%$ of total volume of HFRP bars to ensure the proper bond behaviour. The Figure 1 describes the change of Young's modulus depending on the different levels of fibres volume fractions.

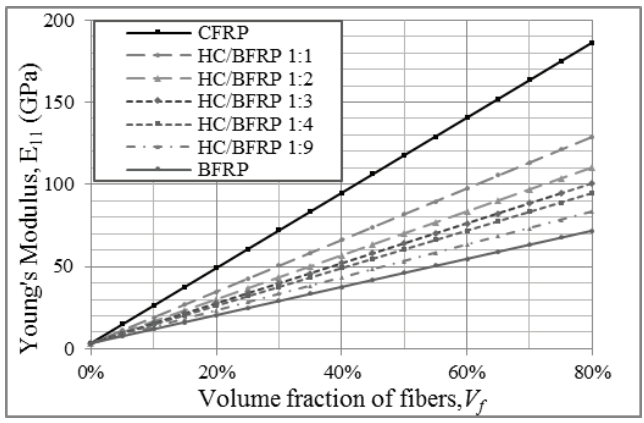

Fig. 1. Theoretical Values of Young's Modulus based on ROM vs. Constituents Volume Fraction for Different Combinations of FRP Bars (C:B - Carbon-to-Basalt Fibres)

The results of analytical considerations indicate that mechanical hybridization of basalt with carbon fibres can positively influence on the Young`s modulus of FRP bars. As an example, the use of the same volume fractions for fibres (at $V_{f}=0,8 \cdot V_{b a r}$ ) (i.e. Carbon-to-Basalt fibres C:B equal to $50 \%$ : $50 \%$ ) can increase the final stiffness by $79,6 \%$ and the use of $10 \%$ of carbon fibres of total fibres content can increase the Young`s modulus of HFRP bars by $16 \%$ comparing to BFRP bars. 


\subsection{The Numerical Simulations}

The need in numerical modelling occurred since the proposed analytical considerations do not regard to fibres arrangement. Some experimental studies [6] suggest that fibres location can be one of the factors influencing on the mechanical properties of HFRP bars. Therefore, authors consider two different bar configurations basing on the fibres arrangement with the aim to estimate its influence on the properties of bars. The two groups of fibres, particularly in a core region and in the near-surface region, were perfectly interconnected for numerical analysis.

The numerical simulation of tensile strength test for HFRP bars was performed by Finite Element Methods (FEM) in software ANSYS ${ }^{\circledR}$ Academic Research Mechanical, Release 16.2 [5]. The bars were represented as cylindrical elements with the diameter of $8 \mathrm{~mm}$ and the length of $850 \mathrm{~mm}$.

The bars were composed of two parts, the core region (cylindrical form) and the surface region (tube form), which were perfectly interconnected. The constant pressure of $500 \mathrm{MPa}$ was applied on side edges along axis $\mathrm{x}$, which is the corresponding axis to longitudinal direction of bars. One central point was fixed in $y$ and $z$ directions. The material properties for the parts were defined as for the orthotropic materials. More information on the numerical simulations can be found in [19, 31].

The obtained results from numerical modelling were compared with analytical considerations and are found to be in a good convergence with each other. The results for different fibres arrangement and different volume fractions of fibres are described in Table 2.

Table 2. Comparison of Young's Modulus Obtained from ROM and FEM Modelling

\begin{tabular}{|c|c|c|c|}
\hline \multirow{3}{*}{$\begin{array}{c}\text { Volume fraction } \\
\text { dependence } \\
\text { C:B }\end{array}$} & \multicolumn{3}{|c|}{ Modulus of elasticity of HFRP bars, GPa } \\
\hline & \multirow{2}{*}{$\begin{array}{c}\text { ROM } \\
\text { The location is } \\
\text { neglected }\end{array}$} & \multicolumn{2}{|c|}{$\begin{array}{c}\text { FEM } \\
\text { Carbon fibres location }\end{array}$} \\
\hline & & 0 & ( \\
\hline 1:9 & 83.3 & 83.0 & 82.9 \\
\hline $1: 4$ & 94.8 & 93.6 & 93.6 \\
\hline $1: 3$ & 100.5 & 101.1 & 100.1 \\
\hline $1: 2$ & 110.0 & 110.5 & 109.1 \\
\hline $1: 1$ & 129.1 & 127.8 & 129.2 \\
\hline
\end{tabular}

The comparison between analytical considerations and numerical simulations of HFRP bars was explained in more details in [30]. Results of numerical modelling showed that the influence of fibres 
arrangement is less important from theoretical point of view than the influence of different volume fractions of fibres. The maximum variation depending on fibres arrangement is less than $2 \%$.

\subsection{TECHNOLOGICAL ISSUES}

The numerical results indicate that fibres arrangement is not of high importance for the final mechanical properties of HFRP bars with different combinations of fibres. However, the slight tendency in obtaining different Young`s modulus was observed; if the volume fraction of carbon fibres is less than $50 \%$ of total amount of fibres, it is better to place carbon fibres in the near-surface region. However, if the carbon fibres volume fraction is more than $50 \%$, the location of them in the core region of bar will be the most appropriate.

Therefore, basing on the results, manufacturing company attempted to produce both configurations. However, while placing carbon fibres in the near-surface layer, several technological issues were observed. These issues include an increased heterogeneity in fibre distribution and local scorching of carbon fibres caused by temperature rises. Figure 2 demonstrates these technological problems. Consequently, it was decided that carbon fibres will be located in the core region of the bar.

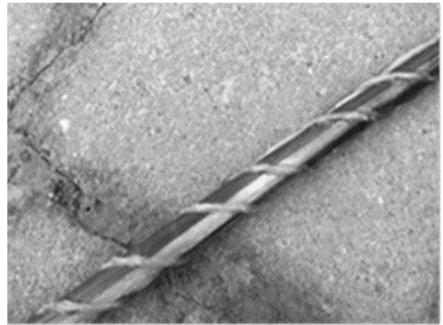

(a)

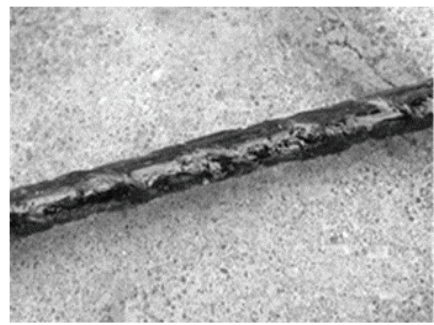

(b)

Fig. 2. Imperfections of HFRP Bars Resulting from Manufacturing Technology:

(a) Non-Homogeneous Distribution of Carbon Fibres; (b) Scorching

\section{EXPERIMENTAL TESTING}

The HFRP and nHFRP bars were produced with a circular cross - section of diameter of $8 \mathrm{~mm}$ - one of the most often bar diameter used in construction. The FRP braids were twisted to improve the adhesion with concrete (the equivalent of ribbing for steel bars). The numerical analyses of different 
options for twisting of the braids can be found in [20]. The selected volume fractions of carbon-tobasalt fibres was assumed as 1:3 (i.e. $16 \%$ of carbon fibres, $64 \%$ of basalt fibres and $20 \%$ of epoxy resin).

The tensile strength test (axial loading) was performed for three types of FRP bars. The tensile strength test was carried out in accordance with [2] standard for pultruded FRP bars. Five sample bars for every type were subjected to tensile testing.

Due to different behaviour of FRP bars in transverse and longitudinal direction the special anchoring at both ends should be used. With this aim, two steel tubes with outer diameter of $40 \mathrm{~mm}$, wall thickness of $5 \mathrm{~mm}$ and the length of $400 \mathrm{~mm}$ each were used. Anchoring tubes parameters has been determined on the basis of previous studies [35]. The empty spacing between bars surface and tubes was filled with special adhesive agent.

Figure 3 shows the sample preparation and test performing (just before the failure).

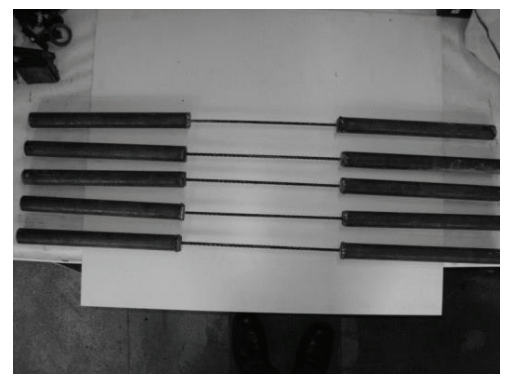

(a)

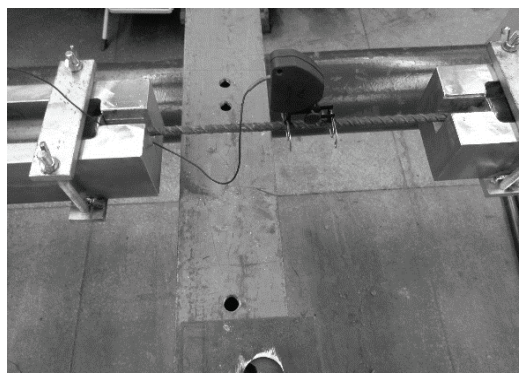

(b)

Fig. 3. The Tensile Strength Testing of the Bars (a) BFRP Bars Prepared for Testing; (b) Setting HPRP Bar in the Machine

The tensile strength of the specimens can be found by dividing the measured maximum load by the transverse cross-sectional area of FRP bars of the corresponding type, $A_{i F R P}$. To experimentally determine the modulus of elasticity of FRP bars the following expression (3.1) can be used, as recommended in [14].

$$
E_{11, i F R P}=\frac{\left(P_{1}-P_{2}\right)}{\left(\varepsilon_{1}-\varepsilon_{2}\right) A_{i F R P}}
$$

where: 
$E_{11, i F R P}$ - Young `s modulus of corresponding FRP bars along longitudinal axis, $P_{1}$ and $P_{2}$ are the applied loads corresponding to $50 \%$ and $25 \%$ of the ultimate load respectively; and $\varepsilon_{1}$ and $\varepsilon_{2}$ are the corresponding strains; $A_{i F R P}$ are the corresponding transverse cross-sectional area of BFRP, HFRP or nHFRP bars, respectively.

Table 3 summarize the result of tensile tests. The mean values of maximum strength, $F_{u}$, limit stress, $f_{u}$, modulus of elasticity, $E_{1}$, and the limit strain, $\varepsilon_{u}$, for BFRP, HFRP and nHFRP bars were defined.

Table 3. Mechanical Properties of Analysed Bars with the Diameter of $8 \mathrm{~mm}$

\begin{tabular}{|c|c|c|c|c|}
\hline $\begin{array}{c}\text { Means value } \\
\text { Ø8mm }\end{array}$ & $\begin{array}{c}\text { Maximum } \\
\text { tensile force } \\
F_{u} \\
{[k N]}\end{array}$ & $\begin{array}{c}\text { Tensile } \\
\text { strength } \\
f_{u} \\
{[M P a]}\end{array}$ & $\begin{array}{c}\text { Tensile } \\
\text { strain at } \\
\text { rupturę } \\
\varepsilon_{u} \\
{[\%]}\end{array}$ & $\begin{array}{c}\text { Modulus of } \\
\text { elasticity } \\
E_{11} \\
{[\mathrm{GPa}]}\end{array}$ \\
\hline BFRP & 60.03 & 1103.30 & 2,52 & 43.87 \\
\hline HFRP & 77.21 & 1277.92 & 1.73 & 73.89 \\
\hline nHFRP & 71.28 & 1223.48 & 1.72 & 71.00 \\
\hline
\end{tabular}

Results indicate that for the HFRP bars with $8 \mathrm{~mm}$ diameter, the coefficient of variation of all the aforementioned properties was slightly above $4 \%$. However, for the BFRP bars it was approximately $2 \%$.

The hybridization of BFRP bars by substituting the part of fibres by carbon fibres can positively influence on the final stiffness of material. The use of the carbon fibres in the proportion carbon fibres-to-basalt fibres 1:3 can increase the Modulus of elasticity from $43.87 \mathrm{GPa}$ to $73.89 \mathrm{GPa}(68 \%)$ and additional modification to nHFRP bars increases the modulus till $71.0 \mathrm{GPa}(61 \%)$.

The samples were destroyed by splitting in similar manner and the destruction mechanism had a brittle character. The mentioned results do not contain all of the properties of nHFRP bars, so, it is difficult to define clearly the effect of modified matrix on the properties of HFRP bars. However, it is seen from the results that modification of epoxy resin had been slightly reduced the overall mechanical properties of HFRP bars.. 


\section{CONCLUSION}

The previous studies suggest that one of shortcomings of the existing BFRP bars is its low modulus of elasticity. The main objective of this study was to develop a viable FRP bars that will balance safety and cost requirements by using the concept of material hybridization.

On the basis of the analytical, numerical (pre-manufacturing) considerations and experimental testing for BFRP, HFRP and nHFRP bars the main conclusions can be drawn:

The numerical results for modulus of elasticity obtained numerically are in good convergence with analytical model (the variation is approx. $2 \%$ ), however, the obtained values were significantly higher (approx. 20\%) than experimental results.

Experimentally it was defined that the modulus of elasticity and tensile strength parameters of HFRP bars $(C: B=1: 3)$ were increased by $68.4 \%$ and $15.8 \%$, respectively, comparing to the properties of BFRP bars. The elongation of HFRP bars was $16 \%$ lower that can be explained by better extension properties of carbon fibres.

Since the numerical/analytical considerations were predicting much better results than it was obtained experimentally, the authors attempted to improve HFRP properties by adding silica nanoparticles to epoxy resin. However, the results for nHFRP bars were lower (3\% at maximum) than for HFRP bars that can be explained by non-homogenous distribution of nanosilica particles in matrix.

To estimate the mechanical behaviour of HFRP bars as internal reinforcement for RC structures the further analyses should be carried out, since the change in the material properties, technological aspects and external factors may affect the overall structural performance of newly-developed bars. The further work on improving the mechanical properties of HFRP bars will be continued and the mentioned directions will be examined.

\section{REFERENCES}

1. American Concrete Institute (ACI). Guide for the design and construction of structural concrete reinforced with FRP bars. ACI: Farmington Hills, USA, 2006; ISBN 9781942727101.

2. American Concrete Institute (ACI). Guide test methods for fiber reinforced polymers (FRPs) for reinforcing or strengthening concrete structures. ACI: Farmington Hills, USA, 2006; ISBN 9780870317811.

3. American Concrete Institute (ACI). Specification for Carbon and Glass Fiber-Reinforced Polymer Bar Materials for Concrete Reinforcement, Farmington Hills, Reapproved 2017, ISBN 9780870312885.

4. American Society of Civil Engineers (ASCE). Recommended Practice for Fiber-Reinforced Polymer Products for Overhead Utility Line Structures. ASCE: Reston, USA, 2003; ISBN 9780784470954.

5. ANSYS ${ }^{\circledR}$ Academic Research Mechanical, Release 16.2, Help System, Coupled Field Analysis Guide, ANSYS, Inc.

6. C.E. Bakis, A. Nanni, J.A. Terosky, S.W. Koehler, "Self-Monitoring, Pseudo-Ductile, Hybrid FRP Reinforcement Rods for Concrete Applications”, Composites Science and Technology, Vol. 61 No. 6, pp. 815823,2001 
7. R.V. Balendran, T.M. Rana, T. Maqsood, W.C. Tang, "Application of FRP bars as reinforcement in civil engineering structures" Structural Survey Vol. 20 No. 2, pp. 62- 72, 2002.

8. E.J. Barbero, "Introduction to composite materials design, 2nd ed.", Taylor \& Francis Group: Boca Raton, USA, pp. 91-100, 2011.

9. J.W. Baur, C. Chen, R.S. Justice, D.W. Schaefer, "Highly dispersed nanosilica-epoxy resins with enhanced mechanical properties", Polymer, Vol. 49, pp. 3805-3815, 2008.

10. T. Black, R. Kosher, "Non Metallic Materials: Plastic, Elastomers, Ceramics and Composites", In Materials and Processing in Manufacturing, 10th ed.; John Wiley \& Sons, USA, pp 162-194, 2008.

11. H.C. Boyle, V.M. Karbhari, "Investigation of Bond Behavior between Glass Fiber Composite Reinforcements and Concrete", Journal of Polymer-Plastics Technology and Engineering, 34 (5), pp. 697-720, 1994.

12. Canadian Standard Association (CSA), Canadian Highway Bridge Design Code (CAN/CSA S6-14). Rexdale, ON, Canada, 2014.

13. Canadian Standard Association (CSA). Design and Construction of Building Structures with Fibre Reinforced Polymers (CAN/CSA S806-12). Rexdale, ON, Canada, 2012.

14. Canadian Standard Association (CSA). Test Method for Tensile Properties of FRP Reinforcement; CSA: Ontario, Kanada, 2002.

15. H.N. Dhakal, Z.Y. Zhang, R. Guthrie, J. MacMullen, N. Bennett, "Development of flax/carbon fibre hybrid composites for enhanced properties", Carbohydrate Polymers, Vol. 96, pp. 1-8, 2013.

16. F. Elgabbas, E. Ahmed, B. Benmokrane "Physical and Mechanical Characteristics of New Basalt-FRP Bars for Reinforcing Concrete Structures", Journal of Construction and Building Materials, Vol. 95, pp. 623-635, 2015.

17. F. Elgabbas, E.A. Ahmed, B. Benmokrane, "Flexural behaviour and bond-dependent coefficient of basalt FRP bars in concrete beams", Resilient Infrastructure, June 1-4, STR-823-1, 2016.

18. T.A. Elsayed, A. Eldaly, A. El-Hefnawy, "Ghanem G. Behaviour of concrete beams reinforced with hybrid fiber reinforced bars", Advanced Composite Materials,Vol. 20 No. 3, pp. 245-259, 2011.

19. A. Garbacz, E.D. Szmigiera, K. Protchenko, M. Urbański, "On Mechanical Characteristics of HFRP Bars with Various Types of Hybridization", In International Congress on Polymers in Concrete (ICPIC 2018). Polymers for Resilient and Sustainable Concrete Infrastructure, 1st ed.; M. M. Reda Taha, U. Girum, \& G. Moneeb; Springer, Volume 1, pp. 653-658, Washington, USA,2018.

20. A. Garbacz, M. Urbański, A. Łapko, "BFRP bars as an alternative reinforcement of concrete structures Compatibility and adhesion issues", Advanced Materials Research, vol. 1129, pp. 233-241, 2015.

21. P.R. Head, "The world's first advanced composite road bridge". In Developments in short and medium span bridge engineering, Symposium on short and medium span bridges, Calgary, Canada, 1994.

22. L.C. Hollaway, "Head Advanced polymer composites and polymers in the civil infrastructure" Elsevier: Amsterdam, Holland, pp. 302-310, 2001.

23. L.C. Hollaway, "Polymer composites for civil and structural engineering", Blackie Academic and Professional: Glasgow, Great Britain, pp. 12-62, 1993.

24. M. Jawaid, H.P.S. Abdul Khalil, "Cellulosic/synthetic fibre reinforced polymer hybrid composites: A review", Carbohydrate Polymers, Vol. 86, pp. 1-18, 2011.

25. T. Jesionowski, R. Pilawka, "Kompozycje epoksydowe z krzemionką", Kompozyty, Vol. 9 No. 2, pp. 112-116, 2009.

26. T. Jesionowski, R. Pilawka, "Kompozyty epoksydowe z krzemionką sieciowane 1-etylomimidazolem" [Epoxy composites with silica crosslinked with 1-ethylimidazole]. Kompozyty 2011, Vol. 11 No. 1, pp. 14-17.

27. G.A. Kashwani, A.K. Al-Tamimi, "Evaluation of FRP bars performance under high temperature", Physics Procedia, Vol. 55, pp. 296-300, 2014.

28. A. Łapko, M. Urbański, "Experimental and theoretical analysis of deflections of concrete beams reinforced with basalt rebar", Archives of Civil and Mechanical Engineering, Vol. 15 No. 1, pp. 223-230, 2015.

29. T. Ovitigala, "Structural Behavior of Concrete Beams Reinforced with Basalt Fiber Reinforced Polymer(BFRP) Bars", PhD Thesis, University of Illinois, Chicago, USA, 2012.

30. K. Protchenko, E. D. Szmigiera,, M. Urbański \& A. Garbacz, "Development of Innovative HFRP Bars", MATEC Web of Conferences, 196, pp. 1-6, 2018. http://doi.org/10.1051/matecconf/201819604087

31. K. Protchenko, J. Dobosz, M. Urbański, A. Garbacz, ”Wpływ substytucji włókien bazaltowych przez włókna węglowe na właściwości mechaniczne prętów B/CFRP (HFRP)", [EN: Influence of substitution of basalt fibres by carbon fibres on mechanical properties of B/CFRP (HFRP)] Czasopismo Inżynierii Lądowej, Środowiska i Architektury, Vol. 63 No. 1/1, pp. 149-156, 2016.

32. K. Protchenko, M. Włodarczyk, E.D. Szmigiera, ’Investigation of Behavior of Reinforced Concrete Elements Strengthened with FRP”, Procedia Engineering, Vol. 111, pp. 679-686, 2015.

33. D.N. Saheb; J.P. Jog, "Natural fiber polymer composites: A review", Advances in Polymer Technology, Vol. 18, pp. 351-363, 1999

34. E.D. Szmigiera, M. Urbański, K. Protchenko, ”Strength Performance of Concrete Beams Reinforced with BFRP Bars", In International Congress on Polymers in Concrete (ICPIC 2018). Polymers for Resilient and Sustainable 
Concrete Infrastructure, 1st ed.; M. M. Reda Taha, U. Girum, \& G. Moneeb; Springer, Volume 1, pp. 667-674, Washington, USA, 2018.

35. M. Urbański, A. Łapko, A. Garbacz, "Investigation on Concrete Beams Reinforced with Basalt Rebars as an Effective Alternative of Conventional R/C Structures”, Procedia Engineering 2013, Vol. 57, pp. 1183-1191.

36. W. Voigt, "Uber die beziehung zwischen den beiden elasticitatsconstanten isotroperkorper". Annals of Physics, Vol. 274 No. 12, pp. 573-587, 1889.

37. B. Wei, H. Cao, S. Song, "Environmental Resistance and Mechanical Performance of Basalt and Glass Fibers", Journal of Materials Science and Engineering: Part A, Vol. 527, pp. 4708-4715, 2010.

38. S. Yehia, G. Kashwani, "Performance of Structures Exposed to Extreme High Temperature-An Overview", Open Journal of Civil Engineering, Vol. 3 No. 3, pp. 154-161, 2013.

\section{LIST OF FIGURES AND TABLES:}

Fig. 1. Theoretical Values of Young's Modulus based on ROM vs. Constituents Volume Fraction for Different Combinations of FRP Bars (C:B - Carbon-to-Basalt Fibres)

Rys. 1. Teoretyczne wartości modułu Younga na podstawie zasady mieszanin vs. udział objętościowy składników dla różnych kombinacji prętów FRP (C:B - włókna węglowe : włókna bazaltowe)

Tab. 1. Properties of Constituents Utilized for Preparing HFRP Bars

Tab. 1. Właściwości składników wykorzystywanych do tworzenia prętów HFRP

Fig. 2. Imperfections of HFRP Bars Resulting from Manufacturing Technology: (a) Non-Homogeneous

Distribution of Carbon Fibres; (b) Scorching

Rys. 2. Niedoskonałości prętów HFRP wynikające podczas produkcji: (a) niejednorodne rozmieszczenie; (b) przypalenie

Tab. 2. Comparison of Young's Modulus Obtained from ROM and FEM Modelling

Tab. 2. Porównanie modułu Younga uzyskanego z zasady mieszanin i modelowania FEM

Fig. 3. The Tensile Strength Testing of the Bars (a) BFRP Bars Prepared for Testing; (b) Setting HPRP Bar in the Machine

Rys. 3. Test wytrzymałości na rozciąganie prętów (a) przygotowanie do badań prętów BFRP; (b) Ustawianie prętów HPRP w urządzeniu

Tab. 3. Mechanical Properties of Analysed Bars with the Diameter of $8 \mathrm{~mm}$

Tab. 3. Właściwości mechaniczne analizowanych prętów o średnicy $8 \mathrm{~mm}$

\section{MECHANICAL PROPERTIES OF HYBRID FRP BARS AND NANO-HYBRID FRP BARS}

Keywords: Fibre-Reinforced Polymers (FRP) bars; Hybrid FRP (HFRP) bars; nano-HFRP (nHFRP) bars; composite reinforcement; Finite Element Analysis (FEA) for FRP bars

\section{SUMMARY:}

The paper describes the recent developments of Hybrid Fibre-Reinforced Polymer (HFRP) and nano-Hybrid FibreReinforced Polymer (nHFRP) bars manufactured using the pultrusion process. Hybridization of less expensive basalt fibres with carbon fibres leads to more sustainable alternative to Basalt-FRP (BFRP) bars and more economically-efficient 
alternative to Carbon-FRP (CFRP) bars. At the same time the properties of the proposed bars can be modified by changing the bars configuration. The New-Developed HFRP bars were subjected to tensile axial loading to investigate its structural behaviour. The effect of hybridization on tensile properties of HFRP bars was verified experimentally by comparing the results of tensile test of HFRP bars with non-hybrid BFRP bars. It is possible to improve and predict the final mechanical characteristics of HFRP bars through mechanical hybridization of constituents and their volume fractions before it will be produced. The analytical/numerical considerations and experimental testing showed the same tendency in obtained results. In pre-manufacturing phase it was set that for the final mechanical properties, the influence of bar configuration is less important than the influence of different volume fractions of fibres. In addition, it was assumed that the preferable location of carbon fibres will be in the core region due to technological problems. It is worth to mention that the difference in obtained strength characteristics between analytical and numerical considerations was very small, however the obtained results were much higher than results obtained experimentally. Authors suggested that lower results obtained experimentally can be explained by imperfect interphase development and therefore attempted to improve the chemical cohesion between constituents by adding nanosilica particles to matrix consistency.

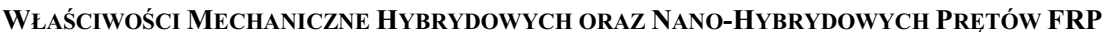

Slowa kluczowe: Pręty FRP (Fibre-Reinforced Polymers); Hybrydowe pręty FRP (HFRP); pręty nano-HFRP; zbrojenie kompozytowe; Metoda Elementów skończonych (MES) dla prętów FRP

\section{Podsumowanie:}

W artykule zostały przedstawione najnowsze postępy w zakresie zachowania mechanicznego hybrydowych prętów FRP (HFRP) oraz nano-hybrydowych (nHFRP) produkowanych w procesie pultruzji. Hybrydyzacja włókien bazaltowych z włóknami węglowymi prowadzi do bardziej zrównoważonej alternatywy dla prętów na bazie włókien bazaltowych (BFRP) i bardziej ekonomicznej alternatywy dla prętów FRP na bazie włókien węglowych (CFRP). Jednocześnie właściwości proponowanych prętów można modyfikować zmieniając ich konfigurację. Nowo opracowane pręty HFRP poddano obciążeniu osiowemu przy rozciąganiu, aby zbadać jego zachowanie strukturalne. Wpływ hybrydyzacji na właściwości mechaniczne prętów HFRP zweryfikowano doświadczalnie, porównując wyniki próby rozciągania prętów HFRP z niehybrydowymi prętami BFRP. Możliwa jest poprawa i przewidywanie końcowych właściwości mechanicznych prętów HFRP poprzez mechaniczną hybrydyzację składników i ich udziałów objętościowych przed ich wyprodukowaniem. Analityczne i numeryczne rozważania oraz badania eksperymentalne wykazały tę samą tendencję w uzyskanych wynikach. W fazie przedprodukcyjnej ustalono, że dla końcowych właściwości mechanicznych wpływ konfiguracji pręta jest mniej ważny niż wpływ różnych udziałów objętościowych włókien. Ponadto założono, że preferowane położenie włókien węglowych będzie zaproponowane bliżej rdzenia prętów ze względu na problemy technologiczne. Warto wspomnieć, że różnica w uzyskanych charakterystykach wytrzymałościowych między rozważaniami analitycznymi i numerycznymi była bardzo mała, jednak uzyskane wyniki były znacznie wyższe niż wyniki uzyskane eksperymentalnie. Autorzy sugerują, że niższe wyniki uzyskane eksperymentalnie można wyjaśnić niedoskonałym rozwojem interfazy i dlatego próbowano poprawić spójność chemiczną między składnikami przez dodanie cząstek nanokrzemionki do konsystencji matrycy. 